\title{
Therapeutic Index of Methanolic Extracts of Three Malaysian Phyllanthus Species on MCF-7 and MCF-10A Cell Lines
}

\author{
Wan Adnan Wan Omar*, Siti Nur Dalila Mohd Zain
}

\section{Wan Adnan Wan Omar*,} Siti Nur Dalila Mohd Zain

Advanced Medical and Dental Institute, Universiti Sains Malaysia, 13200 Kepala Batas, Penang, MALAYSIA.

Correspondence

Dr. Wan Adnan Wan Omar

Advanced Medical and Dental Institute, Universiti Sains Malaysia, 13200 Kepala Batas, Penang, MALAYSIA.

Phone no : +604 5622570

E-mail:wanadnan@usm.my

History

- Submission Date: 29-05-2018;

- Review completed: 02-08-2018.

- Accepted Date: 03-10-2018

DOI : 10.5530/pj.2018.6s.5

Article Available online

http://www.phcogj.com/v10/i6s

Copyright

(C) 2018 Phcog.Net. This is an openaccess article distributed under the terms of the Creative Commons Attribution 4.0 International license.

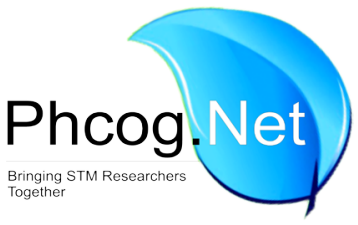

\begin{abstract}
Introduction: Phyllanthus species such as $P$. urinaria, $P$. niruriand $P$. debilis are common herbs found in Malaysia that are traditionally used for treatment of chronic diseases such as liver diseases, kidney stones and cancer. Phyllanthus species were shown in vitro to have many biological functions such as anti-cancer, anti-inflammatory, hepatoprotective and anti-diabetic. Aims: The goal of this in vitro study was to assess the cytotoxic effect of the methanolic extract of P. urinaria, P. niruri and P. debilis on MCF-10A and MCF-7 cells (i.e., normal and cancerous breast cell lines) and to determine the therapeutic index of each Phyllanthus species. Materials and Methods: We determined the therapeutic index for each Phyllanthus sp. and its selective toxicity towards these cells. The toxicity of sample toward the cells are measured by trypan blue cell counting method. Results: Our results showed that $P$. debilis had the lowest $\mathrm{IC}_{50}$ concentration in MCF-7 cells and the highest IC ${ }_{50}$ concentration in MCF-10A cells and its therapeutic index was higher than that found in $P$. niruri and $P$. urinaria. The high therapeutic index of $P$. debilis suggests that this species has greater selective cytotoxicity in MCF-7 cancer cells than in MCF-10A normal cells. Thus, the methanolic extract of $P$. debilis should be further characterised and developed for future use as an anti-cancer agent.

Key words: Cytotoxicity, MCF-7, MCF-10A, Phyllanthus, Therapeutic index.
\end{abstract}

\section{INTRODUCTION}

Phyllanthus is a large genus of trees, shrubs and herbs of the family Euphorbiaceae. The genus contains more than 600 species and is commonly found in tropical regions worldwide. ${ }^{1}$ Phyllanthus species such as P. acidus, $P$. debilis, $P$. pulcher, $P$. reticulatus, $P$. urinaria, $P$. niruri and $P$. myrtifolius are used traditionally for treatment of kidney stones, intestinal infections, cancer, diabetes, hepatitis B and neonatal jaundice. ${ }^{2-4}$ The three species most commonly used to treat certain diseases in Malaysia are P. niruri, P. debilis and P. urinaria. In vitro studies have shown that Phyllanthus species are effective as anti-cancer agents in many types of cell lines.-9 The aim of this study was to evaluate the selective toxicity of the methanolic extract of $P$. urinaria, $P$. debilis and $P$. niruri in normal (MCF-10A) and breast cancer cells (MCF-7). The trypan blue assay was performed to investigate the cytotoxicity effects of the methanolic extracts of $P$. urinaria, $P$. niruri and $P$. debilis on MCF-7 and MCF-10A cells. Cells were treated for 24 hours with medium containing methanol extracts at different concentrations and the $\mathrm{IC}_{50}$ and $\mathrm{EC}_{50}$ were determined for each extract. The therapeutic index was calculated to determine whether the cytotoxic effects of each methanol extract were selective for cancer cells (MCF-7) in comparison to non-cancer cells (MCF-10A). In this study, the therapeutic index is defined as the ratio of the half inhibitory concentra- tion of the extract at which an extract becomes toxic in normal cells and the half effective concentration of the extract at which the drug is effective in cancer cells. $^{10}$

We determined the therapeutic index of these three Phyllanthus species to identify the species with the highest therapeutic index for future development of a chemotherapeutic agent.

\section{MATERIALS AND METHODS}

\section{Samples}

$P$. urinaria, $P$. niruri and $P$. debilis were harvested from the local collection at Tasek Gelugor, Penang, Malaysia. These species were identified by a botanist from the School of Biological Sciences, Universiti Sains Malaysia (USM). Voucher specimens (Phyllanthus debilis: 11623, Phyllanthus niruri: 11624 and Phyllanthus urinaria: 11625) were deposited at the USM herbarium.

\section{Plant extraction}

The whole plant sample were dried and crushed into a powder form. Five grams of sample was then extracted with $100 \mathrm{~mL}$ of methanol in an ultrasonic bath for $20 \mathrm{~min}$. After filtering the filtrate, the process was repeated twice with the remaining residual
Cite this article: Omar WAW, Zain SNDM. Therapeutic Index of Methanolic Extracts of Three Malaysian Phyllanthus Species on MCF-7 and MCF-10A Cell Lines. Pharmacog J. 2018;10(6) Suppl:s30-s32. 
extract. The methanolic extract was then dried using a Buchi Rotary Evaporator RII (Switzerland) and then freeze dried using FDU-1200 Eyela device (USA). The dried extracts were stored at -2 to $-8^{\circ} \mathrm{C}$ for future use.

\section{Cell Culture}

Human breast carcinoma (MCF-7) and human breast epithelial (MCF$10 \mathrm{~A})$ cell lines were used in this study. MCF-7 cells were grown in RPMI-1640 medium (Gibco) and MCF-10A cells were grown in Dulbecco Modified Eagle Medium. The medium for MCF-7 cells was supplemented with $10 \%$ fetal bovine serum (Gibco) and $1 \%$ penicillinstreptomycin (Gibco) and incubated in a humidified atmosphere with $5 \%$ carbon dioxide at $37^{\circ} \mathrm{C}$. The medium for MCF-10A cells was supplemented with $1 \%$ hydrocortisone (Sigma-Aldrich), $1 \%$ penicillin-streptomycin (Gibco), 10\% horse serum (Gibco), 0.25\% human recombinant insulin (Gibco) and $0.002 \%$ recombinant human epidermal growth factor (Gibco) and incubated in a humidified atmosphere with $5 \%$ carbon dioxide at $37^{\circ} \mathrm{C}$. There were two technical replicates for each experiment and each experiment was repeated three times.

\section{Trypan blue cell counting}

Cells were seeded at cell density of $0.05 \times 10^{6}$ cells/well in 24 -well plates and incubated in $5 \%$ carbon dioxide at $37^{\circ} \mathrm{C}$ for $36-48$ hours to allow cell attachment and to reach 70\% confluency. Once the cells reached 70\% confluence, the cells were treated with five different concentrations of the extracts. Both methanolic extract and aqueous extract sample were dissolved in growth medium. The concentration for methanolic extracts ranged from 31.25 to $500 \mu \mathrm{g} / \mathrm{mL}$, while for aqueous extract, the concentration ranged from 62.5 to $1000 \mu \mathrm{g} / \mathrm{mL}$.

The control wells were prepared with cells without treatment. The half inhibitory concentration in normal cell $\left(\mathrm{IC}_{50}\right)$ and half effective concentration in cancer cells $\left(\mathrm{EC}_{50}\right)$ of the extract was determined for MCF-7 and MCF-10A by determined the concentration of extract at which $50 \%$ of the target is inhibited.

Cells were incubated at $37^{\circ} \mathrm{C}$ in $5 \%$ carbon dioxide for another 24 hours. The cells then were washed using phosphate buffered saline (PBS) and incubated with trypsin for $5 \mathrm{~min}$ to detach the cells from the well. Medium was added to the well to deactivate the trypsin and the mixture was thoroughly mixed. The cell suspension was then mixed with $0.4 \%$ trypan blue solution in the ratio of $1: 1$ and $10 \mu \mathrm{L}$ of this suspension were directly counted using a haemocytometer. The average cell count of four fields was used to represent the number of cells per $\mathrm{mL}$ of cell solution, it and was used to determine the total number of cells from each well. The number of cells was counted in each of the four quadrants using the following formula:

Number of cells $=((\mathrm{A}+\mathrm{B}+\mathrm{C}+\mathrm{D}) / 4) \times 10^{4} \times$ dilution factor $\times$ sample dilutions.

The viability of the cells was determined by comparing the number of viable cells in the treatment with that in the untreated group as follows: Percentage of viable cells $(\%)=($ Number of viable cells from treatment $/$ Number of viable cells (untreated) $) \times 100$.

\section{Calculation of therapeutic index}

Therapeutic index was calculated by dividing the $\mathrm{IC}_{50}$ (inhibition concentration of $50 \%$ in normal MCF-10A cells) to $\mathrm{EC}_{50}$ (inhibition concentration of $50 \%$ in MCF-7 cancer cells). $\mathrm{IC}_{50}$ and $\mathrm{EC}_{50}$ were extrapolated from the graphs constructed based on cytotoxicity assay using Microsoft Excel 2016 for Windows.

$$
\text { Therapeutic index }=\mathrm{IC}_{50} / \mathrm{EC}_{50}
$$

Table 1: Effective concentration $\left(\mathrm{EC}_{50}\right)$, inhibitory concentration $\left(\mathrm{IC}_{50}\right)$ and therapeutic index of the methanol extracts from $P$. urinaria, $P$. niruri and $P$. debilis.

\begin{tabular}{cccc}
\hline Species & $\begin{array}{c}\text { MCF-7 } \\
\text { concentration } \\
(\mathrm{mg} / \mathrm{ml})\end{array}$ & $\begin{array}{c}\text { MCF-10A } \\
\mathrm{IC}_{50} \begin{array}{c}\text { concentration } \\
(\mathrm{mg} / \mathrm{ml})\end{array}\end{array}$ & $\begin{array}{c}\text { Therapeutic } \\
\text { index } \\
(\mathrm{TI})\end{array}$ \\
\hline P. urinaria & 0.172 & 0.135 & 0.7848 \\
P. niruri & 0.122 & 0.174 & 1.4262 \\
P. debilis & 0.117 & 0.545 & 4.6581 \\
\hline
\end{tabular}

\section{RESULTS AND DISCUSSION}

Therapeutic index provides a simple index for assessing the safety and efficacy of target drugs. Extracts with high therapeutic index are effective at killing cancer cell at a lower concentration (i.e., the lower $\mathrm{EC}_{50}$ concentration used in cancer cells compared to the higher $\mathrm{IC}_{50}$ concentration in normal cells) than extracts with low therapeutic index. ${ }^{11}$ Table 1 shows the $\mathrm{IC}_{50}, \mathrm{EC}_{50}$ and therapeutic index of each Phyllanthus species.

In the MCF-7 cancer cells, the methanolic extract of $P$. debilis had the lowest $\mathrm{EC}_{50}$ concentration, followed by $P$. niruri and $P$. urinaria. In normal MCF-10A cells, $P$. debilis had the highest $\mathrm{IC}_{50}$ concentration, followed by $P$. niruri and $P$. urinaria. Thus, $P$. debilis had the highest therapeutic index, followed by P. niruri and P. urinaria (Table 1). Higher therapeutic index indicates more selectivity towards cancer cells than normal cells. These results suggest that $P$. debilis has stronger selective cytotoxicity towards MCF-7 cancer cells but lower toxicity to normal MCF-10A cells compared to the other Phyllanthus species tested.

In contrast, $P$. urinaria showed indistinct cytotoxic activity in both MCF-10A and MCF-7 cells. It also had the lowest therapeutic index, suggesting that the methanol extract of $P$. urinaria was the most toxic to MCF-10A cells. However, Lee et al., (2011) reported that the methanolic extract of $P$. urinaria showed better selective toxicity in MCF-7 cells than in normal breast epithelial cells (184B5), with $\mathrm{EC}_{50}$ in MCF-7 cells of $48 \mu \mathrm{g} /$ $\mathrm{mL}$ compared to $\mathrm{IC}_{50}$ at $>500 \mu \mathrm{g} / \mathrm{mL}$ in normal $184 \mathrm{~B} 5$ cells. ${ }^{5}$ This discrepancy between studies might be because different normal breast cell lines were used (MCF-10A and 184B5) and the P. urinaria methanolic extract might affect them differently. The biochemical and biological responses of those cells (MCF-10A and 184B5) are highly variable and the effect of the extract might depend on genetic alterations present in those cells. ${ }^{12}$ Bio-guided assay development and analysis of the compounds present in the methanolic extract are needed to identify the possible compounds responsible for the cytotoxic effect seen in MCF-10A cells.

\section{CONCLUSION}

Methanolic extracts of $P$. urinaria, $P$. niruri and $P$. debilis shows different toxicity towards normal breast cell lines and breast cancer cell lines. This study shows that $P$. debilis had highest therapeutic index, followed by $P$. niruri and P. urinaria. This means that this species is more effective in killing cancer cell at a lower concentration. Further studies are warranted for better understanding of their biological mechanisms.

\section{ACKNOWLEDGEMENT}

The authors gratefully acknowledge the financial support from Universiti Sains Malaysia short term research grant (grant number 304/ CIPPT/6312130).

\section{CONFLICT OF INTEREST}

Authors declare that there is no conflict of interest. 


\section{ABBREVIAITIONS}

MCF-7: Breast cancer cell; MCF-10A: Normal breast cell; IC : $_{50}$ Inhibitory concentration; $\mathbf{E C}_{50}$ : effective concentration, $\mu \mathrm{g} / \mathrm{ml}$ : Microgram per mililiter; ${ }^{\circ} \mathrm{C}$ : Degree celsius; $\mathbf{m g} / \mathbf{m L}$ : Milligram per mililiter; $\mu \mathrm{L}$ : Microliter; min: Minutes; $\mu \mathrm{L}$ : Mililiter.

\section{SUMMARY}

In summary, $P$. debilis had the lowest $\mathrm{EC}_{50}$ concentration in MCF-7 cells and the highest $\mathrm{IC}_{50}$ concentration in MCF-10A compared to $P$. urinaria and $P$. niruri. The therapeutic index for $P$. debilis was higher than $P$. niruri and $P$. urinaria.

\section{REFERENCES}

1. Sabir SM, Rocha JB. Water-extractable phytochemicals from Phyllanthus nirur exhibit distinct in vitro antioxidant and in vivo hepatoprotective activity against paracetamol-induced liver damage in mice. Food Chemistry. 2008;111(4):845-51.

2. Calixto JB, Santos AR, Filho VC, Yunes RA. A review of the plants of the genus Phyllanthus: their chemistry, pharmacology and therapeutic potential. Medicinal Research Reviews. 1998;18(4):225-58.

3. Kumaran A, Karunakaran RJ. Anti-oxidant activity of polyphenols from Phyllanthus debilis Klein ex Wild. Journal of Natural Remedies. 2006:6(2):141-6.

4. Mao X, Wu LF, Guo HL, Chen WJ, CuiYP, Qi Q, et al. The genus Phyllanthus: an ethnopharmacological, phytochemical and pharmacological review. Evidence-
Based Complementary and Alternative Medicine. 2016.

5. Lee SH, Jaganath IB, Wang SM, Sekaran SD. Antimetastatic effects of Phyllanthus on human lung (A549) and breast (MCF-7) cancer cell lines. PLoS One. 2011;6(6):e20994.

6. Araújo JRFD, Souza TPD, Pires JG, Soares LA, Araújo AAD, Petrovick PR, et al. A dry extract of Phyllanthus niruri protects normal cells and induces apoptosis in human liver carcinoma cells. Experimental Biology and Medicine. 2012;237(11):1281-8.

7. Tseng HH, Chen PN, Kuo WH, Wang JW, Chu SC, Hsieh YS. Antimetastatic potentials of Phyllanthus urinaria L on A549 and Lewis lung carcinoma cells via repression of matrix-degrading proteases. Integrative Cancer Therapies. 2012:11(3):267-78.

8. Tang YQ, Jaganath IB, Manikam R, Sekaran SD. Inhibition of MAPKs, Myc/Max, NFאB and hypoxia pathways by Phyllanthus prevents proliferation, metastasis and angiogenesis in human melanoma (MeWo) cancer cell line. International Journal of Medical Sciences. 2014;11(6):564.

9. Nguyen VT, Sakoff JA, Scarlett CJ. Physicochemical Properties, Antioxidant and Cytotoxic Activities of Crude Extracts and Fractions from Phyllanthus amarus. Medicines. 2017:4(2):42.

10. Cha MC, Lin A, Meckling KA. Low dose docosahexaenoic acid protects normal colonic epithelial cells from araC toxicity. BMC Pharmacology. 2005;5(1):7.

11. Deepa PR, Vandhana S, Jayanthi U, Krishnakumar S. Therapeutic and Toxicologic Evaluation of Anti-Lipogenic Agents in Cancer Cells Compared with Non-Neoplastic Cells. Basic and Clinical Pharmacology and Toxicology. 2012;110(6):494-503.

12. Torbett NE, Luna MA, Knight ZA, Houk A, Moasser M, Weiss W, et al. A chemical screen in diverse breast cancer cell lines reveals genetic enhancers and suppressors of sensitivity to PI3K isoform-selective inhibition. Biochemical Journal. 2008:415(1):97-110.

Cite this article: OmarWAW, Zain SNDM. Therapeutic Index of Methanolic Extracts of Three Malaysian Phyllanthus Species on MCF7 and MCF-10A Cell Lines. Pharmacog J. 2018;10(6)Suppl:s30-s32. 